\title{
Skolebøger - grundlag for vor viden
}

af Christian Glenstrup

Fra tid til anden dukker den tanke frem, at skolens historie kunne skrives på grundlag af skolebogen. Det er endnu ikke gjort - og bliver det næppe.

I hvert fald ikke den danske skoles historie.

Måske kan det gøres med lidt større held i et autoritært styret land, hvor statsmagten fuldstændig bestemmer indholdet af den enkelte skolebog og af dens brug i de enkelte skoler og klassetrin.

Men det er ikke tilfældet i Danmark.

Gå ind på en amtscentral for undervisningsmidler og se reolerne med skolebøger, som i dag bruges i danske skoler. For alle fag og klassetrin er der meget at vælge imellem, og åbner vi bøgerne og kigger på indholdet, kan vi finde store forskelle ikke alene i den måde, stoffet er behandlet på, men også i selve stofudvalget, i de emner, der behandles.

Tager vi så til sammenligning nogle ældre skolebøger for tilsvarende fag og klassetrin - og det kan f.eks. gøres i Danmarks Pædagogiske Biblioteks magasiner - vil vi kunne finde forskelle mellem dem indbyrdes, men også, at de på forskellig måde afviger fra de nye. Det kan næppe overraske, for naturligvis er skolebogen et produkt af sin tid, og selv om et studium af skolebogens historie ikke er et tilstrækkeligt grundlag for at skrive skolens historie, kan den være et væsentligt bidrag og et godt udgangspunkt.

"Skolebøgerne er kulturhistorisk og pædagogisk et fascinerende og frugtbart kildemateriale, et særpræget kulturspejl," skriver Vagn SkovgaardPetersen (Skolebogen som kulturhistorisk kilde i: Skolebøger i 200 år) - men han peger så i den videre afhandling både "på de muligheder og de vanskeligheder, materialet byder historikeren". 
Skolebogens historie er en del af skolens og pædagogikkens historie, men kun en del.

Selve det forhold, at der i dagens Danmark er tale om et valg mellem mange muligheder, siger noget om vor skole ikke alene i sammenligning med de førnævnte autoritære stater, men også når vi ser på de lande, vi ellers plejer at sammenligne os med, og spørgsmålet om retten til at vælge er med til at tegne billedet af skolens historie.

I dag er det skolebestyrelsen, hvor forældrene udgør et flertal, der principielt skal godkende alle undervisningsmidler. Sådan har det været siden 1970, da skolenævn med forældrevalgte repræsentanter blev obligatorisk ved alle skoler. Fra vedtagelsen af skoleloven af $1814 \mathrm{og}$ frem til 1970 var det skolekommissionens ret - og pligt - at vælge de bøger, der skulle undervises efter. Før den tid var det de gejstlige myndigheder. I praksis har det siden 1904 i stigende grad været lærerne, der foretog valget, som blev forelagt og normalt godkendt, men i enkelte tilfælde, hvor der var tale om kontroversielle bøger specielt om seksualundervisning og bøger med et politisk indhold, gjorde forældrene brug af deres ret til at afvise disse.

\section{Autoriserede lærebøger i religionsundervisning}

Et særligt forhold gjorde sig gældende for religionsundervisningen. I Kirkeordinansen af 1539 blev det bestemt, at degnene skulle undervise sognets børn i børnelærdommen, dvs. Luthers katekismus, der fremkom i forskellige udgaver. Den fik betegnelsen "lærebog"og blev autoriseret.

På denne måde kom tre "lærebøger" til at præge folkeskolens religionsundervisning i mere end 200 år: Erik Pontoppidan: Sandhed til Gudfrygtighed (1737), N.E. Balle: Lærebog i den evangelisk-christelige Religion (1791) og C.F. Balslev: Luthers Catechismus med en kort Forklaring (1849). Det er den, de fleste af os kender med katekismens spørgsmål og svar, en forklarende kommentar og et par skriftsteder til yderligere bekræftelse. Den er kommet i 347 oplag og helt frem til midten af dette århundrede var den "autoriseret til brug i skolerne og ved konfirmandundervisningen", som det stod at læse på titelbladet.

Det gik ikke altid uden protest. De "stærke jyder" i sognene mellem Horsens og Vejle ville ikke acceptere Balles lærebog, som de fandt for meget præget af rationalismen, men fastholdt Pontoppidans pietistiske lærebog. 
Også fra andet hold kom kritik af katekismen, det var de grundtvigske kredse, der foretrak "det levende ord", fortællingen.

Men katekismen holdt stand. Ved en undersøgelse i 1930 viste det sig, at i 3.053 (af ialt 4.078) skoler blev den stadig brugt i undervisningen.

Undertiden kunne der også være tale om protester fra enkelte forældre. I november 1913 skriver ministeriet som svar på en forespørgsel, at "i Henhold til Anordning af 29. Juli 1814 ... maa Forældre, naar de ønsker, at deres Barn fremdeles skal frekventere Sognets Skole, finde sig i, at Barnet benytter samme Undervisningsmidler som Skolens øvrige Børn."

Det har tilsyneladende ikke været nok. I maj 1914 er der et nyt brev til skoledirektionen som svar på en henvendelse fra den samme skolekommission, der nu spørger, hvilke midler "der staar til Skolens Raadighed for at fremtvinge Overholdelsen af et Forældre givet Paabud om at lade deres Barn benytte den paabudte Bog ved Hjemmeforberedelsen".

Ministeriets svar er: "... saafremt det paagældende Barn ikke opnaar de Kundskaber i vedkommende Fag, som med Rimelighed vil kunne fordres, maa Skolekommissionen være berettiget til at nægte Barnet Opflytning i en højere Klasse, ligesom det, hvis Børnene har Plads i Klassen efter Dygtighed, vil kunne nedflyttes paa en lavere Plads i Klassen."

Ganske vist drejede det sig i dette tilfælde om "de til Brug ved Religionsundervisningen autoriserede Lærebøger", men nogle bemærkninger i ministeriets første skrivelse om muligheden af at lade sognerådet anskaffe dem og "skaffe Udlæget erstattet eventuelt ved Udpantning" mere end antyder, at vi her står over for et andet problem: pligten til at anskaffe og betale.

\section{Hvem betalte skolebøgerne?}

Skoleloven af 1814 fastslog, at det var forældrenes pligt, dog med den vigtige undtagelse, at det offentlige skulle betale "de nødvendigste Lærebøger for fattige Børn, hvis Forældre, Værger eller Huusbonder ikke kunne bekoste samme". Og det gjaldt ikke kun bøgerne, der kom med hjem, for ganske vist blev det pålagt skolen at anskaffe papir, penne og blæk til skriveundervisningen og tavler og grifler, men for de formuendes børn skulle disse udgifter refunderes.

Efter skoleloven af 1899 bliver det kun "taskebøgerne", forældrene skal 
betale, men først med skoleloven af 1937 tager man skridtet fuldt ud og pålægger kommunerne pligten til at betale alle undervisningsmidler. Og så er endda stadig undtaget gymnasiet, hvor bestemmelsen om frie undervisningsmidler først dukker op i 1954.

Betalingsspørgsmålet har været en hindring for princippet om ligestilling, det har kunnet bringe forstyrrelse i hjem-skole forholdene, og det har også efter kommunernes overtagelse af betalingen - været en begrænsning i det frie valg mellem de mange tilbud. I pengeknappe tider er undervisningsmiddelkontoen ofte et af de første steder, der skæres. I en sådan situation skal der gode argumenter til at få lov at anskaffe en ny lærebog til et fag, hvis skolen i forvejen har en, som stadig anses for brugbar.

\section{ABC-erne}

Nye skolelove, ændrede fag- og undervisningsplaner, nye pædagogiske teorier og ændringer i samfundet uden for skolen er nogle af de ting, der trækkeri den anden retning og skaber betingelser og behov for nye skolebøger.

I 1989 udkom en historielærebog beregnet for folkeskolen. Den hed Ole Bole kom i skole. Og forfatteren, Sten Larsen, havde valgt denne titel, fordi han vidste, at vel op imod 1/2 million danskere ved synet af Storm P.s Ole Bole med lap på knæet og tornyster på ryggen ville komme til at tænke på deres egen Ole Bole ABC. Den blev fra 1927 og tredive år frem trykt i 861.000 eksemplarer, og bøgerne gik i arv til flere klasser.

Den kan ikke klare sig i konkurrencen med Luthers katekismus, men til gengæld er det måske med større glæde, vi genser den.

Noget nyt var, at forfatteren, Claus Eskildsen, med bogen Det første Skoleår udgav en udførlig lærervejledning, noget som kom til at danne skole for senere abc-er og læsebogssystemer. To næsten samtidige nåede ikke den samme udbredelse. De var begge baseret på ordbilledmetoden, mens Ole Bole brugte lydmetoden.

ABC-enshistorie er lang. Denførste danske, vi kender af navn, blev trykt i Viborg i 1529. Og ABC-erne fra de næste århundreder lignede hinanden. En side med alfabetet, en side med stavelser og så Fadervor, de ti bud - målet var at kunne læse katekismen. Fælles for dem var også hanen som symbol på årvågenhed. Hanen var sejglivet, men indholdet i abc-erne ændredes. 


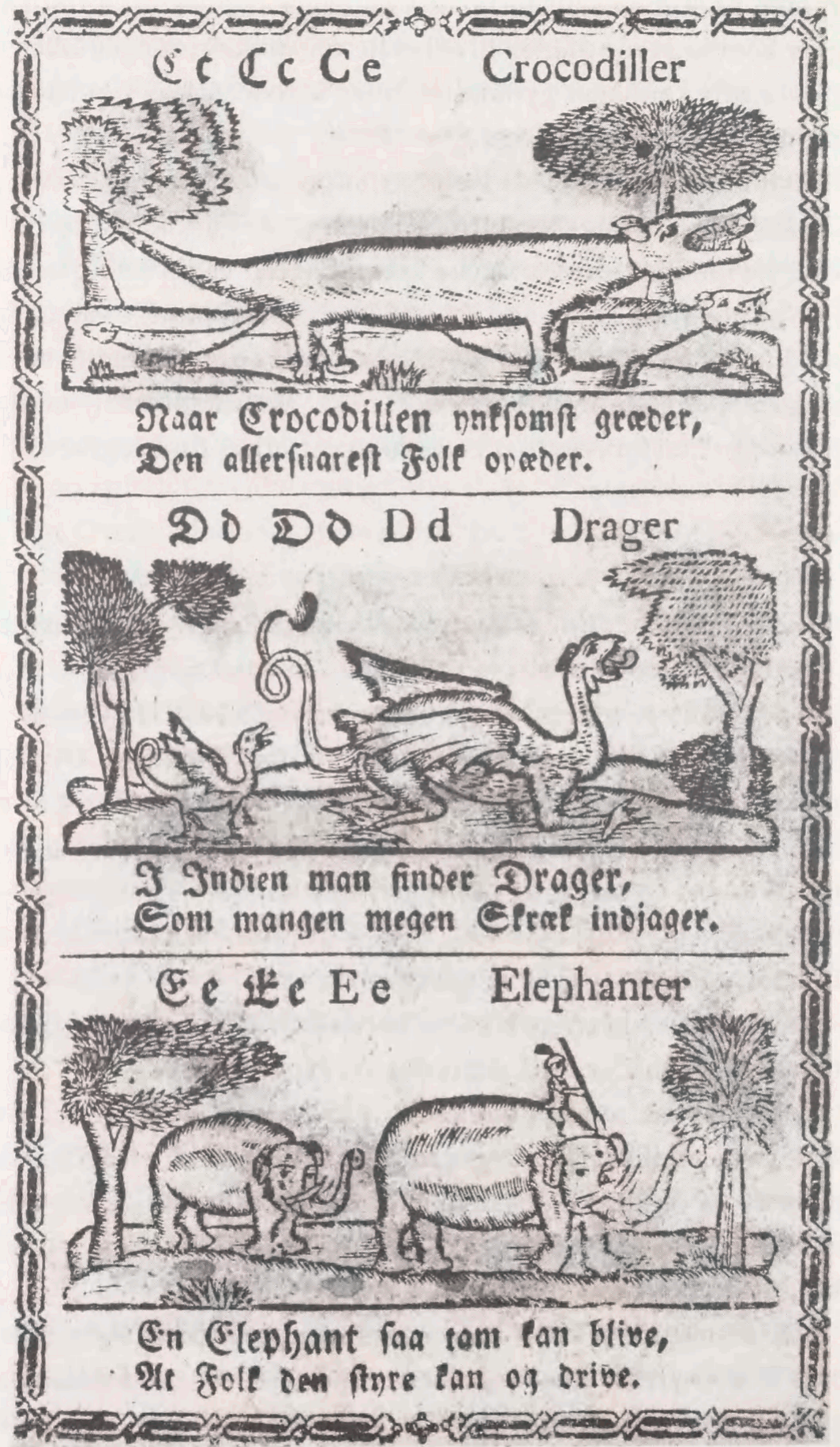

ABC fra omkr. 1770, trykt hos Johan Rudolph Thiele i København. Bogen indeholder håndkolorerede tegninger med små vers. 
Thomas Rasmussen, om hvem det på titelbladet oplyses, at han var "forhen Provst i Grevinge" erstatter i sin ABC og Læsebog (1798) det religiøse stof med små fortællinger, hvor de borgerlige dyder sættes i højsædet. Det er i denne, vi har historien om den dydefulde Kristiane, der som otteårig syede sin egen særk med den tråd, hun selv havde spundet. Der var idealer at leve op til.

Med tiden kommer flere illustrationer, læsestoffet bliver tilpasset, så det bedre svarer til skolebegynderens erfaringsverden, og det indledende øvestof udvides og indrettes efter teorier om den rette læseindlæring: stavemetode, lydmetode, skrive-læsemetode, ordbilledmetode eller sætningsbilledmetode. Og nu er det lærere med undervisningserfaring, der står som forfattere.

\section{Regnebøger}

Også regneundervisningen kommer tidligt ind i den danske skole. Der udkom forskellige regnebøger, men tre udgivere kommer til at dominere undervisningen helt frem til 1900-tallet, og den sidste beholdt endda en del af sin position et godt stykke ind i vort århundrede.

Det var Søren Matthisen: Arithmetica eller Regne=Konst (1696), Christian Cramer: Arithmetica tyronica eller grundig Veiviisning, practice at lære al fornøden Huus=og Handels=Regning (1735) og Chr. Hansen, der udsendte en række regnebøger, tabeller og som noget nyt hovedregningsopgaver .

Fra en undersøgelse i 1880 ved vi, at $87 \%$ af folkeskolerne angav Chr. Hansen som deres system, og i 1894 kunne forlaget på forsiden af et nyudgivet hæfte skrive: "Regnelærer Chr. Hansens Regnebøger med Facitlister ere udkomne i mange og store Oplag, saa at der af de forskellige Hæfter er trykt ialt ca. 2 Millioner Eksemplarer". Det var ikke uden grund, at udtryk som "Det er vist ikke helt efter Christian Hansens regnebog" blev talemåde, når man tvivlede på en udregnings rigtighed.

Matthisen og Cramers lærebøger fandtes i almindelighed kun i et enkelt eksemplar. Til gengæld blev der gjort meget ud af elevens arbejdsbog, kalligraferet med blæk og indeholdende beskrivelser af de forskellige regningsarter, afskrift af opgaverne og elevens egen udregning, indciffring. På første side har eleven skrevet både sit eget og skolens navn samt dato for 
bogens start. En hel del af disse "cifferbøger" findes i dag på vore museer, deriblandt Den Skolehistoriske Samling fra Danmarks Pædagogiske Bibliotek. De har - forståeligt nok - været gemt som familieklenodier.

\section{Læsebøger}

Med folkeskoleloven af 1814 steg behovet for bøger udover den allerførste læsning, og den bog, der i begyndelsen af 1800-tallet dominerede, var David Seidelin Birch: Naturen, Mennesket og Borgeren (1821). Titlen siger noget om indholdet. Der var moraliserende fortællinger nogle i form af fabler, men der var også store afsnit om geografi, astronomi, naturlære, naturhistorie og historie endda med en slags samfundslære. Det var en bog på over 300 sider.

Det gælder også dens efterfølger, Peder Hjort: Den danske Børneven (1838). Peder Hjort, der var professor ved Sorø Akademi blev opfordret til at lave en oversættelse af en tysk bog, Wilmsens Kinderfreund. Han blev så optaget af arbejdet, at han brugte 7 år, men så var det også mere Peder Hjort end Wilmsen. Børnene skulle ikke bare læse, men de skulle tænke over det, de læste, derfor var der hele tiden spørgsmål om det læste. Som noget helt nyt henvendte Hjort sig til sin egen tids digtere. Bla. kollegaen fra Sorø, Christian Wilster, der til bogen skrev digtet om bondeknøsen Hans, der havde været udenlands, og H.C. Andersen bidrog med digtet om konen med æggene begge gengangere i adskillige senere læsebøger. Af andre samtidige forfattere som bl.a. Oehlenschläger, Ingemann og Grundtvig bragte han også digte, men de var ikke skrevet til bogen. Ligeledes førte han i historieafsnittene i de forskellige udgaver stoffet frem omtrent til udgivelsesåret, så den kritik, der ofte er fremsat mod senere tiders litteraturudvalg og historiebøger, at de stopper en generation før deres egen tid, kan ikke rettes mod Hjort.

\section{Fagbøgerne kommer til}

En af de ting, der betegner overgangen til vort århundrede er indførelsen af mellemskolen - først som navnet siger som en skole mellem folkeskolen og den lærde skole, gymnasiet, men meget snart som en del af folkeskolen. Dermed betones behovet for specielle fagbøger i skolen. Det var ikke ukendt. Der var i årenes løb kommet nogle, men både i bibelhistorie, historie og geo- 
grafi var folkeskolens børn nok bedre tjent med lærerens fortælling på grundlag af hans egen læsning, end med lærebøgerne i disse fag. Men mellemskolens indførelse var udtryk for et af tidens slagord: Kundskab er magt, og det stillede krav til lærerne og til lærebøgerne. Det gav også en afsmitning i folkeskolens øvrige klasser - ofte dog sådan, at de behandlede emner var de samme, men bøgerne for folkeskolens klasser var mere kortfattede.

Vilhelm Balslevs naturhistoriebøger: Zoologi i samarbejde med Abrahamsen og Botanik i samarbejde med Kristen Simonsen udkom i disse år både i mellemskole- og folkeskoleudgave - og de holdt skansen så længe, at da faget efter 1958 og "den blå betænkning" kom til at hedde biologi, måtte 30. udgaven også tage navneforandring.

Botanikbøgerne var forsynet med smukke farvetegninger, men teksten blev nok af de fleste opfattet som tørt terperi af antal støvbærere, bladformer m.m.

I historie fik folkeskolen sine egne lærebøger med Nikolaj Nielsen: Danmarkshistorie fra 1888 og Nikoline Helms: Danmarkshistorie (1916). De indeholder begge meget stof, der er egnet til fortælling og som kalder på fantasien, og i dem begge er det nationale stærkt betonet. For mellemskolen blev lærebogen i mange år Ludvig Schmidt (1904), mens P. Munch (1907) var lige så enerådende for gymnasiets vedkommende. Morsomme og spændende var de ikke.

Med fagbøgernes udvikling ændredes læsebøgerne, og med inddragelse af ældre forfattere blev de i stor udstrækning indføringer i den danske litteraturs historie.

\section{Ny pædagogik}

Men ikke alle lærere var tilfreds med udviklingen på skolebogsområdet. Kritikken kom hovedsagelig fra lærerne i grundskolen, 1. - 5. klasse, og fra lærerne i de 6. og 7. klasser, der blev til overs, når mellemskolen havde taget sin del - og den blev større og større for hvert år. Udtrykket "til overs" vil nok skurre i manges øren, for det stemmer dårligt med de demokratiserings- og lighedstanker, vi plejer at fremhæve i forbindelse med skolelovene 18991903. Men desværre må vi nok erkende, at det var sådan, mange elever, deres forældre og også mange lærere oplevede situationen. Der var for både elever 
og lærere prestige at hente i mellemskolen, men ikke i 6. og 7. klasse.

Inspirationen kom i første omgang fra Tyskland og USA. Danske lærere drog på studierejser, læste faglitteratur om nye undervisningsmetoder og ny opdragelse.

Særlig tre ting trådte frem som krav til undervisningen - og dermed til skolebøgerne:

Man skal tage udgangspunkt i barnets natur og udvikling. Vom Kinde aus hed det i Tyskland.

Børn skal lære ikke kun ved at modtage (lytte og læse), men ved at gøre og erfare. Learning by doing, sagde Dewey i Amerika.

Vi skal tage hensyn til det enkelte barn - individuel undervisning.

Det gik lidt trægt med at få disse ting ind i skolebogen. Men det satte gang i forsøgsundervisning. Vanløse skoles forsøgsklasser er de mest kendte, men ikke de eneste, og for skolebøgerne fik nogle af de andre forsøg større betydning. I København blev oprettet studiekredse om undervisningsmidler til individuel undervisning.

Et resultat af disse studiekredse blev en omsætning til dansk af det amerikanske Winnetka-system i form af regnesystemet Individuel Taltræning (1939-41) udarbejdet af E. Floris m.fl.

Til begynderundervisningen i dansk blev resultatet Helge Jensen, Torben Gregersen og Inger Merete Nordentoft: Min egen Bog (1939). Umiddelbart slog bogen ikke rigtig igennem. En årsag var måske, at materialerne, der hørte til bogen - billedkort, liniekort og ordkort - ikke blev brugt. Men indirekte fik den en stor betydning. Forud for udarbejdelsen blev foretaget en optælling af ordforrådet i de mest brugte begynderbøger til læsning og senere udvidet med småbørnsbøger og de såkaldte frilæsningsbøger. Det viste sig, at de fleste begynderbøger ialt indholdt ca. 10.000 ord, deraf 2000 forskellige, som skulle læres, før man kunne læse bogen helt. Ved at bruge opgørelsen, blev antallet af nye ord i Min egen Bog begrænset til 360, selv om det samlede ordantal også i denne var omkring 10.000. Den blev lettere at læse. Metoden blev fremover brugt, når nye begyndersystemer dukkede op, når der skulle skrives frilæsningsbøger og supplerende hæfter til læsebegynderne ikke alene i danskundervisningen, men også i de forskellige orienteringsfag, og også ved udarbejdelsen af de egentlige lærebøger.

Axel Nielsen: Geografisk Tegne- og Arbejdsbog (1931), der senere blev 
Ole Bole ABC fra 1927, udarbejdet af Claus Eskildsen og med tegninger af Robert Storm Petersen. Den nok mest udbredte $A B C$, trykt i 861.000 eksemplarer.

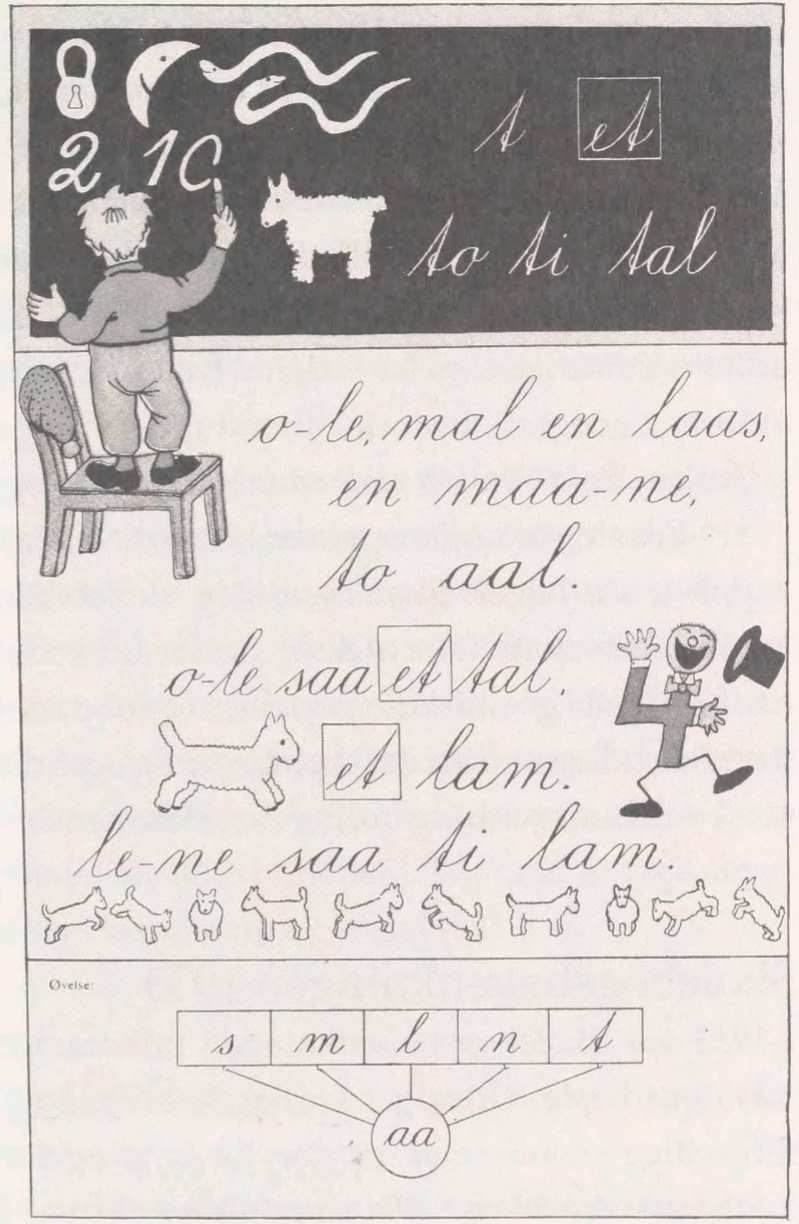

suppleret med naturhistoriskeog hans geografi for folkeskolen (Vor Jord, 1936), blev betragtet som et stort fremskridt, selv om en senere tid måske nok vil finde, at det var så som så med barnets selvvirksomhed, men de kom da til at bruge fingrene, når de på deres egne kvadrerede ark kopierede de stiliserede tegninger og farvelagde dem. De blev brugt og det blev hans idé også i flere senere udgivelser til forskellige fag.

\section{'Fri Mellem'}

I 6. og 7. klasserne blev der specielt i København og på Frederiksberg udført et stort forsøgsarbejde samtidig med, at et udvalg nedsat af undervisningsministeriet arbejdede med undervisningsplaner for disse klasser. Resultatet 
blev, at de sammen med en frivillig 8. klasse i 1937 loven fik navnet Den eksamensfri Mellemskole, og at emneundervisning blev anbefalet som en kombination af fagene dansk, geografi, historie, naturhistorie og evt. naturlære. Det sidste kunne også kombineres med praktisk arbejde i faget fysiksløjd, hvor eleverne selv fremstillede en del apparater til fysikforsøg.

De emnebøger, der udkom, indeholdt eksempler på, hvordan man udfra et emne f.eks. en landsdel, et fremmed land eller en tidsperiode kunne inddrage geografi, historie, litteratur o.s.v., og opgaver, hvoraf nogle med udgangspunkt i emnet trænede retskrivning og stavning.

Løsning af nogle opgaver krævede opslag i håndbøger og læsning af supplerende bøger. Skolelæsestuer, skolebiblioteker og klassebiblioteker kunne levere materialer til dette, og det dukkede også op i form af bøger eller hæfter. Også i grundskolens klasser vandt dette indpas. Men til trods for, at der både udkom en hel del skolebøger og også metodisk litteratur, blev hverken emneundervisningen eller den eksamensfri mellemskole nogen succes.

\section{Skolebogsbetænkningen 1933}

I 1933 var Skolebogsbetænkningen udkommet som resultat af et 3-årigt udvalgsarbejde. Udvalget kortlagde brugen af de enkelte lærebøger i de forskellige skoleformer, opgjort amtsvis og fordelt på købstadsskoler og landsbyskoler. Noget tilsvarende blev gjort af Danmarks Lærerforening i 1880 , men bortset fra disse to undersøgelser har vi ikke nogen samlet oversigt over lærebøgernes udbredelse og anvendelse udover forlagenes oplysninger om oplag og udgaver.

Lærebøgerne til fagene dansk, historie, religion og geografi blev grundigt gennemgået. Udvalget havde fået pålagt at undersøge, om lærebøgernei disse fag var præget af en "videnskabelig, kulturhistorisk og fredsvenlig ånd". Det var ventet - og frygtet af mange, at et resultat ville blive et ministerielt cirkulære. Der var også udkast til to om undervisningen i historie og religion. Protesten var stærkest fra kirkelig side. Den var velforberedt og så gennemført, at den fik tilslutning fra alle kirkelige retninger. Resultatet var, at kristendomsundervisningen gik uantastet over i 1937-loven. Og den revision af fagets bøger, som udvalget havde lagt op til, kom vist først med Åge Nørfelt: Børnenes bibelhistorie med tilhørende Lærerens bog (1958), hvor vi 
for første gang i en skolebog træffer udtrykket: Myter om verdens skabelse og de første mennesker.

Men betænkningen fik betydning på skolebogsområdet. Den indeholdt en lang række eksempler fra de nævnte fags lærebøger på formuleringer, som udvalget fandt uheldige, fordi de gav falske billeder og var bedre egnede til at opbygge og vedligeholde fordomme end skabe reel oplysning. Geografibøgernes korte beskrivelser af befolkningen i forskellige lande leverede mange bidrag til listen.

Der var ikke nævnt navne ved citaterne, men forfatterne havde ikke svært ved at genkende dem, og det fik konsekvenser for senere udgaver.

Også udefra kom der kritik. Internationale organisationer som foreningen Norden og - efter 2. verdenskrig - Unesco rettede specielt blikket mod historie- og geografibøgernes behandlinger f.eks. af forholdet mellem nabostater, og fagbevægelsen fulgte herhjemme trop med to pjecer udsendt af skoleudvalget under Specialarbejderforbundet i Danmark (SID), hvor skolen og lærebøgerne kritiseres for ikke i tilstrækkelig grad at tage sig af emner som arbejderbevægelse, klassekamp og social nød.

\section{Skoleloven af 1958 og derefter}

Der var stadig brug for nytænkning og forbedringer.

Skoleloven af 1958 og den tilhørende undervisningsvejledning, den blå betænkning bliver det officielle startskud til en lang og til tider meget heftig diskussion af skolen, dens fag og dens lærebøger.

Der lægges hårdt ud med en påstand om, at skolebøgerne "har udøvet en form for tyranni. I hvert fald har de haft en overordentlig stærk autoritet." Baggrunden for påstanden er en konstatering af, at der i mange tilfælde i undervisningsplaner kun har været henvist til sidetallet $i$ en eller anden lærebog. Kritikken følges op med mere direkte adresse til lærebogsforfatterne, der beskyldes for i deres stofudvalg at ville have for meget med specielt for orienteringsfagenes vedkommende. De skal opgive tanken om "en ligelig behandling af den enorme stofmængde, der står til rådighed" for "forståelse af væsentlige træk er mere værdifuld end mængden af kendsgerninger, hvortil der ikke knytter sig klare forestillinger".

Lærebogen skal først og fremmest skabe interesse og give redskaber til 
at arbejde fagligt. Disse redskaber kan derefter udnyttes i et arbejde, hvor stoffet kan hentes mange steder fra, temahæfter, tidsskrifter, aviser, håndbøger, romaner, men også egne erfaringer og bearbejdninger. Det giver mulighed for at tilfredsstille kravene om selvvirksomhed, medbestemmelse i valg af arbejdsopgaver, individuel undervisning og undervisningsdifferentiering (ikke alle elever behøver at arbejde med de samme opgaver), og for tværfagligt samarbejde. Der er tale om en klar understregning af, at lærebogen ikke er det eneste undervisningsmiddel, og det pointeres yderligere i undervisningsvejledningen til de forskellige fag.

Hvordan er det så gået?

Der er naturligvis mange variationer, men et hovedprincip for orienteringsfagene har været, at lærebogen med den kortfattede tekst og opremsning af de mange kendsgerninger for på en gang at dække hele stoffet er forsvundet. Den er erstattet af brede skildringer af udvalgte temaer, ofte endda som særskilte hæfter. Det giver mulighed for mange og varierede indgange til fagene, og det åbner for brug i forskellige sammenhænge også i et tværfagligt samarbejde.

Udvalget er mangedoblet og mindre overskueligt; det stiller derfor større krav til underviseren om at forholde sig til undervisningsplanens bestemmelser og vælge det materiale, som passer til situationen, og som kan skabe baggrund for opgaver, der appellerer til den enkelte elevs selvvirksomhed og giver lyst til at arbejde videre, også i en situation, hvor holdet eller klassen både med hensyn til kundskaber, færdigheder og interesser udviser en stor spredning. Det er de krav, vi mødte i 30'ernes reformbestræbelser og i den blå betænkning. Men umiddelbart ser det ud til, at vore dages orientering i 7., 8. og 9. klasserne får mere held end emneundervisningen. Lærebøgerne skal nok have deres del af æren, men måske ikke den hele.

K.E. Bugge: Vi har rel'gion. Et skolefags historie 1900-1975, 1979.

Tage Kampmann, Ingrid Markussen, Ellen Nørgaard og Vagn SkovgaardPetersen: Et folk kom i skole. 1814-1989, 1989 (kap. 3, 7 og 8).
Poul Müller: Gamle danske ABC-er og læsebøger. I: Bogvennen, 1948.

Poul Müller: Af almuedrengens skoletaske. I: Af landsbyskolens saga, 1964. Vagn Skovgaard-Petersen (red.): Skolebøger $i 200$ år, 1970. 